\title{
TURISMO DE LUXO: \\ A PRODUÇÃO DO DESTINO E A DENEGAÇÃO DO SOCIAL
}

\section{LUXURY TOURISM: THE DESTINATION PRODUCTION AND THE SOCIAL DENEGATION}

\author{
Michel Nicolau Netto* \\ Juliana Closel Miraldi**
}

\section{Introdução}

0 mercado de luxo foi destinado tradicionalmente aos consumidores das frações altas da classe dominante e, como tal, esteve sempre relacionado às estratégias de produção e reprodução das posições objetivas do espaço social. Na contemporaneidade, os operadores do luxo (lojas, revistas especializadas, instituições como a que analisaremos aqui etc.) desafiam essa noção e propõem que vivemos na era do new luxury. Por essa noção, tem-se a proposta de que o consumo do luxo é uma "experiência" única e individualizada e que teria havido uma "democratização" de seu mercado, que agora estaria disponível para "qualquer pessoa".
0 luxo, nesse sentido, ganharia novos contornos: deixaria de ser associado à ostentação e ao excesso e passaria a se apresentar como uma escolha íntima e democraticamente disponivel. Esses dois movimentos sustentam um elemento novo e central do mercado de luxo que identificamos como a denegação do social. Com esse conceito retomamos a noção bourdieusiana de denegação, ressignificando-a. Enquanto a denegação em Bourdieu (1994, p. 149) está intimamente associada ao desinteresse econômico e é utilizada para explicar espaços de produção simbólica nos quais o interesse por galgar posições dominantes estrutura-se pelo velamento, neste texto o conceito de Bourdieu é articulado para explicar a estrutura de denegação singular

\footnotetext{
* Doutor em Sociologia pela Universidade Estadual de Campinas - Unicamp. Professor do Departamento Sociologia do IFCH/Unicamp (Campinas/SP/BR). mnicolau@unicamp.br.

** Doutoranda em sociologia pelo Programa de Pós-Graduação em Sociologia do IFCH/Unicamp (Campinas/SP/BR). Mestre em sociologia pela mesma instituição. julianamiraldi@gmail.com.
} 
do mercado de luxo, que consiste em apresentar o luxo como desvinculado de condicionantes sociais que permitem seu acesso.

Por isso nos referimos à denegação do social, que estabelece uma nova lógica de hierarquização das práticas de distinção das classes dominantes. Os agentes do mercado de luxo buscam separar a noção da diferença daquela da distinção. A diferença se basearia em variados estilos de vida centrados em "escolhas" individuais que não estariam relacionadas à posição de classe. 0 consumidor do luxo é apresentado como um iluminado, que sozinho trilha caminhos que o fazem "descobrir" o que ninguém havia antes descoberto. Dessa forma, a diferença dos estilos de vida, algo sempre positivo no mercado de luxo, é negada como distinção. Ao transferir o luxo do âmbito social para o individual, esse mercado vela a hierarquia ativa das práticas e os processos de classificação tanto dessas práticas quanto de seus praticantes. É justamente nessa denegação do social que o luxo encontra condições de ser penetrante nas formas de organização da diferença na contemporaneidade.

Esse princípio pode ser encontrado nos diversos setores do mercado de luxo, e este artigo se centrará no mercado do turismo de luxo. Um importante elemento que caracteriza esse mercado é a existência da rede Virtuoso, uma empresa capaz de unificar o mercado e concentrar poder simbólico, econômico e social. Dessa forma, pode-se observar a partir dessa instituição a produção do discurso da denegação social e como ele se repete entre os agenciadores do luxo ligados a ela.

Por isso, a rede Virtuoso foi o foco privilegiado desta pesquisa, que empreendeu a seguinte metodologia: em primeiro lugar, foram pesquisados os materiais da rede Virtuoso disponíveis na internet; em seguida, foi feito um levantamento de todas as agências de viagem brasileiras que são membros dessa instituição (28 no total); partiu-se, então, para uma investigação nos websites de todas essas agências, dos quais foram recolhidos os discursos e os destinos por elas ofertados. A partir dessas informações levantadas, foram empreendidas entrevistas. Foram duas entrevistas aprofundadas: a primeira delas se deu com a representante de uma das maiores agências de turismo de luxo do Brasil; a segunda foi feita com o representante da rede Virtuoso no Brasil. Por fim, participamos do Virtuoso Networking Cocktail, ocorrido no Hotel Intercontinental, em São Paulo, no dia dois de maio de 2016. Esse evento se voltou para a geração de negócios entre agências de turismo e fornecedores que fazem parte da rede Virtuoso. Além de serem observadas as práticas envolvidas no evento, foi aplicado um questionário curto a oito agências e/ ou fornecedores da rede.

Antes de se partir para a análise, é necessário um esclarecimento. Muito embora não haja aqui o interesse em promover uma discussão sobre o conceito de classe, é preciso que se deixe claro que a noção de classe empregada nesta pesquisa se baseia nas relações práticas entre indivíduos estabelecidos em posições objetivas no espaço social. Dessa forma, ela não é dada a priori, mas em ato. No turismo de luxo, pode-se operar com duas formações de classe. Uma formação é a fração alta da classe dominante, composta por indivíduos habituados ao luxo. São os ricos, como pensaram Michel Pinçon e Monique Pinçon-Charlot (2007), que acumulam uma riqueza multidimensional, ou seja, que não é apenas econômica, mas também social e cultural. A riqueza dessa fração não está somente no acúmulo de capital econômico, mas também no domínio das formas mais legítimas relacionadas ao estilo de vida, ao corpo e ao gosto. 
Aos indivíduos que participam do mercado de luxo, mas que não possuem esse acúmulo multidimensional de riqueza, associaremos as frações médias da classe dominante. Os indivíduos dessa fração não são habituados ao luxo, sendo o luxo para eles sempre um objeto de aprendizado, e precisam passar por processos pedagógicos que lhes permitam reconhecer as hierarquias e classificações veladas do luxo. Em outras palavras, os agentes da fração média aprendem o luxo, enquanto os agentes das frações altas trazem o luxo incorporado. Ao usarmos os termos média e alta, seguimos a forma como o mercado compreende esses indivíduos. Ao insistirmos que são parte de uma fração da classe dominante, nós os posicionamos de forma objetiva no espaço social.

Os destinos turísticos, como concluirá este artigo, são produzidos simbolicamente dentro dessas classificações e podem funcionar como elemento de distinção, programado pela indústria do turismo. Interessante notar que, quanto mais distintiva for a viagem para determinado lugar, mais a indústria atribuirá ao viajante a sua "descoberta”. Dessa forma, é possivel concluir que na escolha do próprio lugar ao qual se viaja opera-se a denegação do social.

\section{0 mercado global do turismo}

Embora uma prática de viagem chamada de turismo nos remeta aos Grand Tou$r s^{1}$ do século XVII, ela não havia adquirido alguns dos contornos que reconhecemos a partir a segunda metade do século XIX. A fundação da empresa de Thomas Cook, em 1841, marca o surgimento das operadoras de viagem, que passam a vender um "pacote turístico" que envolve "o cooperativismo entre as empresas e outros componentes do mercado turístico (agência de viagens, hotéis, transportadoras, restaurantes, atrações, etc.)” (REJOWSKI, 2002, p. 55). Rapidamente a viagem organizada em grupo se torna prática comum em muitos lugares. Cook abre filiais em vários países e seus pacotes, assim como os dos novos concorrentes, passam vender um número cada vez maior de destinos. Em 1907, um navio a vapor traz ao Rio de Janeiro o primeiro grupo organizado de turistas, em ação da empresa Cook\&tSons (MOLINA, 2015, p. 49).

Se a prática da viagem organizada por empresas especializadas se torna comum no fim do século XIX, só se pode dizer que ela se massifica a partir da segunda metade do século XX. Antecede esse momento uma série de inovações técnicas e sociais que contribui para que o turismo se torne uma prática comum para além das classes dominantes. Entre as inovações técnicas, destacam-se o desenvolvimento dos transportes (de rodagem, férreo e aéreo) e seu correspondente barateamento ${ }^{2}$. Em relação às inovações sociais, o surgimento da garantia legal das férias pagas, a partir da década de 1930 na Europa e nos Estados Unidos (WEISS, 2004; LÖFGREN, 1999; ARON, 1999) e em vários países a partir década de 1950, permite uma grande expansão do

1. No século XVII se desenvolve uma nova forma de viagem, quando jovens aristocratas europeus, especialmente ingleses, passaram a fazer um giro pela Europa ao fim de sua educação formal. É conhecida a tutoria de Adam Smith em um Grand Tour (REJOWSKI, 2002, p. 32), da mesma forma que sabemos das visitas de James Boswell, ainda com 24 anos, a Rousseau e Voltaire em um Grand Tour nos anos 1760 (BRADY, 1955).

2. Na década de 1960, a Laker Airlines já oferece os primeiros voos destinados a pessoas de renda mais baixa (BARANOWSKI, 2003, p. 562-563). 
número de potenciais turistas, alcançando os trabalhadores ${ }^{3}$. Com incentivos de campanhas governamentais e de marketing das empresas de turismo, é nesse momento que o par férias e viagem se forma. 0 calendário anual de pessoas de muitos lugares passa a separar os meses do trabalho dos meses do lazer; correspondentemente, os meses em que se está em casa dos meses em que se deve viajar. 0 aumento da quantidade de potenciais turistas e a organização do calendário dividido entre lazer e trabalho, com uma renda para o lazer garantida pelo trabalho, permite a expansão e uma maior racionalização das empresas ligadas ao turismo e, dessa forma, uma maior exploração econômica da viagem. Surgem, assim, espaços produzidos especialmente para a prática do turismo, como os grandes parques temáticos (a Disneylândia é fundada em 1955), as cidades criadas para serem destinos turísticos - como Cancun, no México, na década de 1960 (HIERNAUX-NICOLAS, 1999) - e, posteriormente, as diversas bolhas turísticas (JUDD, 1999) nas cidades, como os revitalizados centros históricos, as recorrentes ilhas de museus, orlas de praia etc.

A intensa expansão do turismo o torna, no século XX, "uma das características da experiência moderna” (URRY, 2001, p. 19), uma prática que todos compartilham, ainda que apenas em expectativas, pois mesmo aqueles que ficam em casa se unem ao universo da viagem pelos filmes, pelos programas de televisão, pelos relatos de amigos. Os cientistas sociais imediatamente buscaram compreender as motivações que levavam as pessoas a viajar. Embora Dean MacCannell (1976), de maneira bastante influente, tenha buscado propor uma causa primeira de toda viagem (a busca pela experiência autêntica $)^{4}$, pode-se dizer que a bibliografia do fim dos anos 1970 e início dos anos 1980 se esforça em reconhecer diferentes motivações para a viagem. Surgem diversas tipologias que buscam dar conta dessas motivações. Stanley Plog, por exemplo, refere-se a turistas "alocêntricos" e “psicocêntricos”, para diferenciar, respectivamente, aqueles que "ativamente buscam os destinos exóticos ou não tocados” daqueles que "não assumem riscos e tendem a ir a destinos turísticos bem estabelecidos" (In: Burns 1999) ${ }^{5}$.

0 que nos interessa notar nessa bibliografia é que, com mais ou menos tipos, encontram-se duas tendências aparentemente contraditórias na representação do turista. De um lado, a bibliografia da década de 1970 e o modo como a indústria se organiza revelam que, ainda que as viagens possam ser diferentes, motivadas por razões diversas, torna-se possível organizar a prática e o agente que a pratica em torno de categorias globais: respectivamente, o turismo e o turista. Contudo, nessas categorias os agentes participantes tentam se

3. Para entender a dimensão do processo, entre 1950 e 1973 a quantidade de chegadas internacionais no mundo aumentou de 25,3 milhões para 198,9 milhões (REJOWSKI; SOLHA, 2002), ou seja, houve um crescimento de oito vezes em 23 anos.

4. A indústria do turismo de massa, segue MacCannell, se especializa, assim, em explorar essa suposta motivação primeira do turista. Mediada por essa indústria, contudo, a autenticidade que o turista experimenta nunca pode ser real, sendo mais bem caracterizada por uma "autenticidade encenada" (MACCANNELL, 1976).

5. Ver em Burns (1999) outras tipologias. Note-se que o turista, para essa bibliografia da década de 1970, é sempre percebido como ocidental. 
diferenciar uns dos outros, abrindo a possibilidade para os analistas de categorizar os turistas em diferentes tipos e o turismo em diferentes segmentos ${ }^{6}$.

Essa tensão diferenciadora em um mercado que se unifica é central para que possamos entender o objeto deste artigo. Até o século XX, o turismo é uma prática distintiva, cuja distinção se baseia na própria possibilidade de sua prática. Ou seja, o turismo distinguia as pessoas ao diferenciar aqueles que viajavam daqueles que não o faziam. A partir da segunda metade do século XX, com a ampliação do acesso à prática da viagem, a distinção produzida pelo turismo precisa se embasar em outro processo: a partir do momento em que todos viajam, ao menos em expectativas, isto é, a partir do momento em que o turismo se torna um dos elementos que ordena o tempo e as aspirações subjetivas, as formas de viajar e os destinos para onde se viaja produzem a distinção.

John Urry faz um diagnóstico do turismo na atualidade que vai nessa direção ao estudar a produção social do olhar do turista. Seu argumento central é que o olhar daquele que viaja "é socialmente organizado e sistematizado" (URRY, 2001, p. 16), ou seja, se modifica entre diferentes sociedades e diferentes tempos. Isso significa que o olhar do turista não é aleatório; para onde se olha, quando se olha, o que se olha é resultado de uma forma de depuração que escapa a sua própria intenção e que pode ser compreendido pela análise das estruturas sociais que constituem a visão de mundo dos agen- tes. Dessa forma, Urry nota as mudanças do olhar do turista nos últimos 150 anos. Em seus termos, na contemporaneidade surge um "paradigma cultural relativamente novo, o pós-moderno", que produz um novo tipo de turista, o "pós-turista". Enquanto "o modernismo tem se refletido na tentativa de tratar as pessoas que se situam em lugar socialmente diferenciado como semelhantes entre si”, "uma das características fundamentais do pós-modernismo é a recusa das pessoas em aceitar serem tratadas como parte de uma massa indiferenciada" (URRY, 2001, p. 123, itálico do autor). Queremos manter da análise de Urry justamente esse elemento: o turismo se torna hoje uma prática socialmente diferenciadora. Contudo, essa diferenciação não se dá mais entre os que viajam e os que não viajam, mas nas maneiras de se viajar, ou seja, nas práticas. A indústria do turismo deve, assim, ao mesmo tempo estimular a ampliação do mercado turístico e oferecer aos viajantes diferentes formas de viajar. Nessas diferenças está, assim, a possibilidade de os viajantes se diferenciarem uns dos outros.

A ampliação de oferta de produtos turísticos (URRY, 2001, p. 70) se coloca justamente nessa direção. Façamos aqui uma breve defınição de termos. Produto turístico pode ser entendido como tudo aquilo que assume um sentido dado ou explorado pelo turismo. Esses produtos podem ser de dois tipos: a) objetos do espaço, como museus, parques, orlas de praia etc.; ou b) unidades espaciais amplas, tais quais cidades, países e regiões. A essas unidades daremos o nome

6. Valene Smith (1989, p. 4-6) categorizava os tipos de turismo em 1977 em: turismo étnico, turismo cultural, turismo histórico, turismo ambiental e turismo recreacional. Já adiantando o que veremos a seguir, tenhamos em mente que hoje o mercado trabalha com 40 tipos de turismo, como se nota em catálogos de feiras de turismo. Aqui nos baseamos no catálogo de uma das maiores feiras do setor do mundo, FITUR -Madrid. Fizemos pesquisa na edição de 2014 dessa feira. 
de destinos turísticos. Tanto os destinos quanto os objetos turísticos se relacionam (não exclusivamente, é evidente) com a prática do turismo e são, assim, comercializados como produtos pelos agentes do setor.

Como ilustração da notável ampliação da oferta desses produtos, a Unesco afirma que, "junto ao dramático aumento no turismo cultural nas décadas recentes, o número de museus ao redor do mundo aumentou de 22.000 em 1975 para 55.000 hoje" Certamente dados semelhantes para outros objetos turísticos poderiam ser trazidos, mas lembremos apenas mais um, retirado de trabalho de campo: uma das principais tarefas dos órgãos públicos de turismo hoje é aumentar o número de atrações e roteiros turísticos disponíveis em cada lugar ${ }^{8}$.

Além dos objetos turísticos, a ampliação dos produtos que se tornam turísticos pode ser notada pela proliferação de destinos ocorrida recentemente. É preciso notar que apenas recentemente o turismo se globalizou, tanto em relação às origens geográficas de quem viaja quanto aos lugares que se tornam destinos. Em relação aos turistas, ainda em 1995 havia 623 milhões de partidas para países estrangeiros, sendo 50\% destas feitas a partir dos Estados Unidos e da União Europeia. Em 2014, quando houve pouco mais de 1 bilhão de partidas, 37\% destas tiveram origem nesses territórios. Desde 2012, a China se tornou o país com o maior número de partidas internacionais do mundo, o que envolveu, em 2014, 98 milhões de pessoas ${ }^{9}$. Em relação aos destinos, em 1950 apenas 5\% das chegadas internacionais ocorriam fora dos Estados Unidos e da Europa (BRASIL, 2010, p. 30). Em 2014, esse número chegava a $52 \%{ }^{10}$.

Dessa forma, hoje o turismo é uma prática global e todos os países do mundo se tornam potenciais receptores e emissores de turistas. Pode-se dizer o mesmo das cidades: são cada vez mais raras aquelas que não fazem parte desse mercado. Para se ter uma ideia, o mapa turístico brasileiro de 2013 identificou 3.345 municípios brasileiros $^{11}$ que possuíam, minimamente, hospedagem e expectativa de recebimento de turistas internacionais e/ou domésticos. Isso significa que 60\% dos municípios brasileiros são, potencialmente, turísticos ${ }^{12}$. Porém, identificar um processo de expansão em escala global na oferta de destinos turísticos é diferente de afirmar que todos esses destinos encontram-se nas mesmas condições de receber turistas.

7. UNITED NATIONS EDUCATIONAL, SCIENTIFIC AND CULTURAL ORGANIZATION. Museums. Disponivel em: <http://en.unesco.org/themes/museums>. Acesso em: 22 jul. 2016.

8. Ver NICOLAU NETTO, M. A hierarquização simbólica do Brasil na Copa do Mundo. [no prelo a ser publicado na revista Sociedade e Estado/UnB].

9. Até 2012, a Alemanha detinha o posto do país com o maior número de viajantes internacionais, com 83 milhões de partidas (THE WORLD BANK, 2016).

10. Ibidem.

11. Fonte: MINISTÉRIO DO TURISMO. Categorização dos municipios das regions turísticas do mapa do turismo brasileiro, 2013. Disponivel em: <http://mapa.turismo.gov.br/mapa/downloads/pdf/categorizacao/ Cartilha_da_Categorizacao.pdf>. Acesso em: 20 dez. 2016.

12. Segundo o IBGE, em 2013 o Brasil chegou a 5.570 municípios (BRASIL. Cresce número de municípios no Brasil. Portal Brasil. 27 jun. 2016. Disponível em: <http://www.brasil.gov.br/economia-e-emprego/2013/06/cresce-numero-de-municipios-no-brasil-em-2013>. Acesso em: 22 jul. 2016). 
Se por um lado ao turista se abrem inúmeras possibilidades de destino (com a globalização do turismo e com a ampliação dos produtos e destinos turísticos), por outro nota-se que seu fluxo não é tão diverso e a concentração em certos destinos é marcante. Dez países recebem 53,6\% dos turistas mundiais ${ }^{13}$. Em relação ao caso brasileiro exposto acima, lembremos que o Ministério do Turismo distribui os 3.345 municípios brasileiros presentes no mapa turístico em cinco categorias, de acordo com os pontos alcançados em termos de hospedagem e capacidade de atração de turistas. Dessa forma, apenas 1,51\% (51) dos municípios presentes no mapa está na categoria A; 4,99\% estão na categoria $B ; 15,1 \%$, na categoria C. As categorias D e E concentram 78,42\% dos municípios. São os municípios das categorias A e B (que somam 6,50\% do total do corpus) que concentram 96\% das expectativas de fluxo de turistas internacionais ${ }^{14}$.

Esses dados revelam que a ampliação do mercado de turismo e a diversidade de oferta não são processos opostos à concentração do fluxo turístico. Embora os turistas possam ir a diversos lugares, há fatores sociais que tendem a levá-los a certos lugares. A escolha da viagem, travestida de um ato individual, tem em si condicionantes sociais velados que correspondem (i) à estrutura atual do mercado de turismo, isto é, a forma como ele se organiza objetiva e discursivamente e (ii) à trajetória social do agente, que leva em conta a posição ocupada histórica e atualmente por ele no espaço social. Deste modo, o ato decisório do turista, longe de ser livre e indetermi- nado, é sempre o efeito do encontro entre esses dois fatores que, em termos bourdieusianos, pode ser compreendido como o encontro entre um espaço de possíveis determinado pelo mercado do turismo e a lógica de possíveis do agente dada pela sua trajetória de vida que organiza aspirações e determina condicionamentos subjetivos. Por isso, a relação de status entre viajante e destino é central para essa compreensão. 0 turismo se torna um mercado globalmente unificado, ou seja, uma prática comum a um contingente grande da população mundial e com destinos de todo o mundo. Ao mesmo tempo, torna-se um mercado hierarquizado, no qual os destinos possuem seus valores que se relacionam diretamente com as práticas dos sujeitos que os visitam. Em outras palavras, os destinos se tornam classificados e elementos de classificação das práticas.

É justamente nisso que se encerra o turismo de luxo. Para tanto, como já demonstrou Bourdieu a respeito dos espaços nos quais predomina a economia simbólica, para que a hierarquia de práticas operacionalizadas nessa relação seja efıcaz, ela deve aparecer na forma denegada (BOURDIEU, 1994, p. 173) A identificação da presença denegada de hierarquias nas práticas de turismo, em especial do turismo de luxo, aliada à análise dos discursos produzidos por agenciadores do luxo, conduziu à tese aqui defendida de que a eficácia desse setor deve-se, ao menos em grande parte, a sua capacidade de velar, de tornar subterrânea a escolha do destino como elemento classificatório. Imediatamente, tudo se passa

13. São eles, na ordem: China (incluindo Hong Kong e Macau), França, Estados Unidos, Espanha, Itália, Turquia, Alemanha, Reino Unido, Rússia e México (THE WORLD BANK, 2016).

14. Idem nota 11. 
como se estivéssemos diante de escolhas individuais, conscientes e indeterminadas. Do lado do turista, haverá uma série de elementos que velam sua busca por status na escolha de seu destino e de sua condição de classe. A noção de experiência é elemento central. Do lado do destino, elementos também velarão sua produção como forma de distinção. A noção de descoberta se destaca. Não à toa, experiência e descoberta são os dois elementos mais constantes nos discursos dos operadores de turismo de luxo que investigamos ${ }^{15}$.

\section{0 novo luxo e a denegação do social}

0 luxo foi objeto de debates morais que podem ser apreciados ao longo da história das ideias. Na Antiguidade, o luxo aparece sobretudo de maneira negativa, associado ao vício e à decadência. De acordo com Paul Veyne, em Roma um homem virtuoso era aquele que resistia "ao micróbio do luxo e da decadência” (VEYNE, 1992, p. 29). Também em Sêneca nota-se o luxo associado a uma imagem negativa: um "demônio" que "confunde a ordem das coisas" (SÊNECA, 1973, p. 198). No século XVIII é possível notar que o discurso a respeito da função social do luxo modifica-se: ao invés de ser tratado como via de corrupção e degeneração dos seres humanos e dos governos, ele passa a ser considerado necessário para promover o desenvolvimento econômico das nações, o avanço das artes e da indústria e o bem-estar da população. Autores como Hume ${ }^{16}$ (1992) e Mandeville (1998) ${ }^{17}$ compreendem que aquilo que é atribuído pejorativamente ao luxo não decorria dele propriamente, mas de uma má política e de uma má administração ${ }^{18}$. Ao luxo é assimilada a ideia de progresso eco-

15. É interessante notar como o turismo de luxo se aproxima, nesse sentido, daquilo que Dean MacCannell chama de tendência ao "turismo moral". Para MacCannell (2011, p. 39), esse turismo é marcado pela preocupação com o ambiente e com as populações locais, mas, do ponto de vista dos turistas, há a preocupação de não serem "meros turistas". Isso é bem captado na noção de "turismo criativo", uma das recentes categorias do mercado de turismo que se volta a turistas "desejosos de realizar uma atividade artística e criativa que lhes permita descobrir a cultura de seu destino, compartilhando momentos privilegiados com seus habitantes. [...] 0 turista criativo será exigente quanto à singularidade das experiências propostas, que serão determinantes para a escolha de seu destino" (CREATIVE TOURISM, 2014). Assim, os discursos do turismo moral e do turismo de luxo estão muito próximos. Seria possível levantar aqui uma hipótese de que tal proximidade se dá porque seus praticantes estão muito próximos no espaço social, em termos de acúmulo de capital cultural e capital econômico, diferenciando-se em razão da importância de cada capital (maior importância do capital cultural para o turista moral; maior importância do capital econômico para o turista de luxo). Deixemos, contudo, essa questão para uma futura análise.

16. Hume, em seu ensaio of refinement in the arts (1992, p. 307-309), considera que o luxo é um vício vantajoso e benéfico para o indivíduo e para o público, ao contrário da preguiça e da ociosidade.

17. Em La fable des abeilles, Mandeville compreende os vícios associados ao luxo - a cobiça, a vaidade e o orgulho - como fatores de desenvolvimento econômico e estímulo militar. Seriam eles o motor da economia, pois sem eles não seriam feitas "mais vestimentas que o necessário (...) e, por consequência, não haveria a metade do consumo nem um terço dos trabalhadores que existem atualmente (...) o comércio não pode ter melhor sustentação que o orgulho" (MANDEVILLE, 1998, p. 120).

18. Na Enciclopédia, Diderot e d'Alembert defınem o luxo como "o uso que é feito da riqueza e da indústria para obter uma existência agradável" (1988, p. 763, tradução nossa); assim, a "causa primeira" do luxo seria o descontentamento do homem com seu estado atual, o que o impulsiona a se tornar melhor. 
nômico, mas também político e moral dos povos. No século XIX e no começo do XX, contudo, o luxo é percebido de forma invertida. Imbuído de uma ética protestante, o espírito do capitalismo moderno se desenvolvia pela formação de uma conduta de vida sistemática que tornava o trabalho um dever e seus frutos apenas válidos quando reinvestidos no próprio trabalho. 0 luxo, mostra Weber (2004), é visto como perda de tempo e adoração da criatura, que se colocava na contramão do desenvolvimento desse espírito.

Não contaremos aqui a história do luxo (MCNEIL; RIELLO, 2016), mas notaremos as novidades que se apresentam na contemporaneidade. Seja em momento de crítica, seja de celebração, o luxo sempre foi objeto de discussões morais baseadas em questões sociais. Em outras palavras, o luxo sempre foi visto como próprio de uma classe e os debates morais em torno dele partiam desse pressuposto. Dessa forma, não se pode dizer que o luxo se referia a um mercado, uma vez que sua própria existência só era possível pela negação do consumo: o luxo era aquilo que não se podia consumir, uma vez que pertencente a apenas uma classe social.

$\mathrm{Na}$ contemporaneidade, contudo, luxo se define como um mercado e, como tal, algo disponível para um consumo irrestrito, desde que se disponha de recursos para tanto. Há, portanto, um deslocamento da problemática: de objeto de discussões morais centradas em questões sociais, o luxo passa a ocupar uma posição central nas estratégias de marketing e de ganhos econômicos e simbólicos, tanto das empresas quanto dos consumidores. É esse processo que o mercado e os especialistas marcam como o "novo luxo", um luxo que estaria, agora, disponível a todos. A expressão, de fato, parece bastante presente: uma busca no "Google Acadêmico" nos traz 587 artigos $^{19}$ com a expressão "new luxury" no título e a revista Forbes, uma das referências no tema, tem uma seção on-line com a mesma expressão ${ }^{20}$.

Vários autores da área de marketing, que se dedicam a esse mercado, marcam a década de 1980 como o momento em que um novo luxo teria surgido. Uma autora da área argumenta que "1984 marca o nascimento ofıcial do 'novo' luxo”, coincidindo com a eleição de Reagan para a presidência dos Estados Unidos, que teria significado tanto um momento de crescimento econômico naquele país quanto uma celebração do consumismo, simbolizada "na paixão de Mrs. Reagan por roupas caras de designers" (DANZIGER, 2005, p. 2). Não importa aqui a marcação temporal em si, mas a expectativa dos especialistas e agentes do mercado de luxo de que estaríamos vivendo um novo momento.

Há dois elementos que definem esse novo luxo, de acordo com a bibliografia do marketing e os discursos do mercado. 0 primeiro se relaciona à noção de que o luxo hoje se individualiza ao extremo. Seu consumo não nos leva mais ao progresso da humanidade, uma visão, de resto, estranha à nossa época (ORTIZ, 2015), mas leva nossos sentidos a um outro patamar. A noção de experiência se torna central nesse mercado. "0 novo luxo", afirma aquela autora,

19. Busca feita apenas com o termo em inglês, limitado ao título (GOOGLE ACADÊMICO. Disponível em: $<$ https://scholar.google.com.br/>. Acesso em: 03 set. 2016).

20. FORBES. New Luxury [Seção especial]. Disponivel em: <http://www.forbes.com/new-luxury/>. Acesso em 03 set. 2016. 
"toca em uma nova psicologia do consumidor que transcende o produto ou a coisa que está sendo comprada ou consumida para alcançar um novo nível de experiência aprimorada, sentido mais profundo, prazer mais rico, sentimentos mais intensos" (DANZIGER, 2005, p. xii). É justamente a experiência que transcende o produto que toma o lugar antes ocupado pelo significante "progresso", indicando, portanto, que o consumo do luxo na contemporaneidade se relacionaria a um prazer individual e não mais a uma questão social.

0 segundo elemento se relaciona à noção de “democratização". Até recentemente seria impensável se referir ao mercado de luxo sem relacioná-lo, exclusivamente, às frações altas de uma sociedade, de modo que havia uma correspondência entre a posição social ocupada por um agente e as suas práticas de consumo (BOURDIEU, 2002). Hoje, ao contrário, o mercado insiste que o luxo seria para todos. As grandes marcas esforçam-se para criar setores mais “democráticos" de produtos. Notamos o mesmo diagnóstico em pesquisas de mercado e em artigos acadêmicos: o mercado de luxo contemporâneo engloba um novo público consumidor que não pertence à tradicional classe dominante. Diz um autor da área que, "desde os anos 1980, a massa dos consumidores do luxo não são os ricos, mas a classe-média, seus vizinhos e suas crianças" (TWITCHELL, 2002, p. 1) ${ }^{21}$.

Esses dois elementos discursivos dos agenciadores do luxo - experiência e demo- cratização - sustentam uma concepção de luxo que se afirma como independente de diferenças sociais. Ele estaria disponível a todos, que o praticam por satisfação pessoal: consumir ou não um produto de luxo aparece como uma escolha individual e não como o efeito de uma posição social que relaciona condição econômica de possibilidade e gosto estético de determinado grupo social.

Um problema clássico da sociologia emerge dessa nova concepção de luxo: uma vez que cresce o acesso ao mercado de luxo e que nesse mercado se discursa no sentido da equiparação dos seus frequentadores, de que maneira as distinções se constroem? Como se pode conciliar um discurso de generalização do consumo com um mercado que, na prática, se baseia na separação entre os indivíduos? A globalização e a formação de grandes conglomerados de empresas de luxo são dois processos centrais que dão suporte para a produção do discurso do novo luxo ${ }^{22}$.

Até recentemente, a relação entre o status de um produto no mercado e a classe social do público consumidor era direta. Em todas as análises clássicas, de Veblen a Bourdieu, passando por Simmel, nota-se uma clara homologia entre a posição do produto no mercado e do consumidor no espaço social. A moda, para Simmel (2014), era um consumo das frações altas da classe dominante, uma vez que a posição da moda no mercado dos bens de consumo era homóloga à da classe que a consumia. Qualquer forma de ruptura da relação era

21. A socióloga Rachel Sherman (2007, p. 296) cita alguns outros autores do marketing que tematizam o novo luxo. Ver Silverstein; Fiske, 2003; Turrell, 2004.

22. Como afirma Varella, "a entrada em cena das grandes holdings coincide com a internacionalização do mercado do luxo. 'É difícil dizer quem é o ovo e quem é a galinha, mas o fato é que hoje a moda está de tal forma globalizada que só as marcas que têm o apoio financeiro dos grandes grupos sobrevivem em grande escala', explica o consultor de moda Jean-Jacques Picart” (In: Freitas Júnior 2012, p. 12). 
pensada pelos autores como um consumo derivado, em geral como uma forma desastrada de emulação. De fato, Veblen (2015) define como emulação pecuniária o consumo das classes baixas que copia o consumo conspícuo típico das classes altas. Bourdieu é o autor que mais detalhadamente analisou essa relação e em todo seu trabalho afirmou repetidamente haver uma forma de consumo cultural das classes altas (baseada no que chamou de desinteresse), uma das classes médias (baseada na "boa vontade cultural") e outra das baixas (baseada na necessidade).

A oposição principal entre os gostos de luxo e os gostos de necessidade especifica-se em um número de oposições iguais às diferentes maneiras de afirmar sua distinção em relação à classe operária e a suas necessidades primárias ou, o que dá no mesmo, igual aos poderes que permitem manter a necessidade à distância. (BOURDIEU, 2002, p. 174)

O luxo, portanto, só poderia ser o consumo da fração alta da classe dominante. Essa homologia era garantida pelo fato de as empresas e os consumidores habitarem uma mesma sociedade nacional. Ainda que certas cidades, especialmente Paris, ocupassem a posição de centros irradiadores das hierarquias do gosto internacional, essas hierarquias se estruturavam nacionalmente. Recentemente, contudo, esse panorama se modifica. De um lado, as empresas se globalizam. As empresas do luxo, como as Grandes Maisons, foram por muito tem- po empresas de bases familiares, mas passaram recentemente a enfrentar concorrentes e investidores estrangeiros, com suas estratégias agressivas de marketing global (LIPOVETSKY; ROUX, 2005, p. 95). Para sobreviver aos novos ingressantes em seu mercado, tradicionais empresas precisaram modificar suas operações, transformandose em grandes conglomerados de operações globais. A Louis Vuitton, por exemplo, foi fundada na França em 1854, para a venda de malas e bolsas. Em 2017, é um grande conglomerado de capital aberto sob o acrônimo LVMH, que reúne setenta marcas de diversos setores: moda e acessórios (Louis Vuitton, Dior, Givenchy, Kenzo, Marc Jacobs, Donna Karan); vinhos e bebidas alcoólicas (Moët \& Chandon, Don Pérignon, Veuve Clicquot, Hennessy); perfumes e cosméticos (Dior, Guerlain, Acqua di Parma, Make up for ever, Fresh); relógios e joalheria (Bulgari, Tag Hauer, Dior Montres) ${ }^{23}$.

Também os clientes dessas marcas se globalizaram. Retomando a LVMH, o grupo hoje opera em 50 países, com mais de 460 lojas espalhadas pelo mundo. A distribuição do faturamento do grupo demonstra como a operação é global: 29\% na Ásia (excluindo o Japão), 24\% nos Estados Unidos, 19\% na Europa (excluindo a França), 11\% em outros mercados e 7\% no Japão. Apenas 10\% do faturamento do grupo é gerado na França, sendo boa parte deste proveniente de turistas estrangeiros (LVMH, 2015, p. 18).

No caminho para a operação global, essas marcas encontram novos concorrentes. É o caso de novas empresas que passaram a

23. Além da LVMH, outros dois grandes conglomerados se destacam pela importância das marcas que reúnem e pelo montante de capital que movimentam: a Kering (antiga Pinault-Printemps-Redoute S.A. PPR), que inclui grandes marcas de luxo como Yves Saint Laurent, Stella McCartney e Gucci, e a Richemont, que possui as marcas Monblanc, Chloé e Cartier. 
fazer parte desse mercado e também de outras que não surgiram no mercado de luxo, mas que se esforçam em ressignificar seus produtos como tal. Empresas como a CAtA, que hoje contrata estilistas e modelos consagrados para se posicionar no mercado de luxo, fazem o mesmo que a empresa Kmart fez nos EUA nos anos 1980. Afinal, diz um autor da área que o "movimento central no mundo do marketing desde os anos 1980 tem sido mais e mais elevar os objetos para marcas de luxo" (TWITCHELL, 2002, p. xv).

Dessa forma, as empresas de luxo precisam adotar uma lógica racional, orientada globalmente, pela qual a expansão incessante de mercado se sobrepõe a toda outra lógica. Tal expansão não se dá apenas em termos geográficos, mas também em uma busca por consumidores de outros estratos sociais. 0 que está em jogo não é mais apenas o consumidor de classe alta nacional, mas também um grande grupo de potenciais compradores espalhados pelo mundo que deve ser conquistado. A posição do diretor atual do grupo LVMH, Bernard Arnault, quando questionado sobre as atuais tendências do mercado de luxo, expressa de maneira clara as transformações: "a primeira é a diversidade de nossa clientela: clientes ricos estão procurando uma exclusividade cada vez maior, mas com o boom em países emergentes, o aumento dos consumidores jovens de classe média fazendo sua primeira entrada no luxo é uma subcorrente" (LVMH, 2015, p. 14). De fato, em uma pesquisa feita por B. Dubois e C. Paternault (1997) em sete países (Estados Unidos, Japão e cinco países europeus) foi possível notar que aproximadamente $40 \%$ da população consome produtos classificados como de luxo. Em todos esses países a porcentagem de consumidores regulares é de cerca de 10\%, que são responsáveis por
$50 \%$ do valor consumido; já os consumidores ocasionais variam de 25\% na Espanha a 38\% na Itália. Como a classe alta desses países não corresponde à porcentagem dos consumidores de luxo, confirma-se a penetração das marcas de luxo em outros estratos sociais.

A ampliação e globalização do público do luxo leva o mercado a buscar novas formas de se referir a esse público. A referência à classe social se torna muito restritiva e o mercado passa a preferir a adoção do termo “democratização”. Pamela Danziger (2005, p. 8) resume essa estratégia comercial ao afirmar que "o novo consumidor de luxo de hoje abraça um ideal democrático do luxo - que é para todo mundo e diferente para todo mundo". Revela-se, assim, a tentativa de um mercado que busca expandir seu nível de produção e consumo e, ao mesmo tempo, manter elementos ligados à exclusividade, em que embasa o valor de seus produtos.

Como manter a imagem de que o luxo é simultaneamente inclusivo e exclusivo, isto é, que está ao alcance de todos e é destinado somente para alguns? Um argumento central mobilizado por esse mercado consiste em defender que o luxo é algo alheio a qualquer forma de distinção:

membros desta geração trocaram espiritualidade por materialidade, paisagem por marcas, Giotto por Gucci, mas eles realmente têm algo nunca visto antes: uma cultura flashdance que não faz qualquer distinção (outra que o desejo por gastar) e é compartilhada pelo grupo da frente e o grupo de trás, todos os gêneros, todas as cores, todos tipos, todos de uma vez. (TWITCHELL, 2002, p. ix, $x$ )

Contudo, quando observamos mais de perto a posição do luxo hoje, notamos que 
há uma equivocidade entre o discurso do mercado sobre a diferença e a maneira como ele a operacionaliza. Isso não significa dizer que a diferença foi abandonada; ao contrário, ela é mobilizada pelo mercado de luxo. Ocorre que há uma cisão entre a noção de diferença - compreendida como uma escolha individual - e a de distinção - entendida como desigualdade de acesso a bens materiais e simbólicos. Assim, a diferença se torna internalizada e não se referiria à distinção. Sua relação com o luxo não se daria pelo contexto social, mas pelo desejo pessoal de sentir prazer. 0 consumo conspícuo, que Veblen descreveu, teria sido substituído por uma forma de consumo individualizado.

O velho luxo era sobre atributos, qualidades e características do produto, e muito de seu apelo derivava do status e do prestígio. 0 novo luxo define a categoria a partir do ponto de vista do consumidor. Os consumidores do novo luxo de hoje focam na experiência do luxo incorporada nos produtos e serviços que compram, não na propriedade ou posse em si. Assim, o novo luxo é sobre a experiência do luxo a partir da perspectiva do consumidor, onde o velho luxo permanece focado no tradicional status e prestígio ideal do luxo. (DANZIGER, 2005, p. 7)

Tudo se passa, portanto, como se o luxo não fosse mais classificado, nem classificante; como se não tivesse relação com a classe social ou com o desejo de pertencimento a certa classe.

A noção de experiência é central na articulação desse argumento. Aqui não será possível retomar toda uma bibliografia sobre o tema, mas é preciso lembrar que, embora compartilhem alguns pressupostos, a bibliografia mais científica que trata da experiência é bastante diferente daquela que o mercado e as pessoas de marketing assumem. De semelhante há dois pressupostos: 1) vivemos em uma sociedade na qual a propriedade das coisas importa menos do que seu uso; 2) a experiência se relaciona a prazeres individuais, que não são socialmente compartilhados (HOLBROOK; HIRSCHMAN, 1982; SCHULZE, 2005). Os textos de marketing, contudo, vão além e entendem a noção de experiência como oposta à visão de uma sociedade de classes. Evidentemente, essa posição encontra vozes dissonantes no campo das ciências sociais. Jon Sundbo (2008, p. 8), por exemplo, defende que "a produção e o consumo das experiências se tornam um fator central de se alcançar status social". Paurav Shukla (2012), por sua vez, tenta demonstrar que há uma separação entre aqueles que consomem por experiência e aqueles que consomem por exibição de acordo com suas procedências territoriais. Embora com resultados bastante questionáveis, ao defender que os orientais são mais propensos a consumir o luxo para demonstração de riqueza do que os ocidentais, o autor busca compreender o tema da experiência em razão de diferenças sociais.

0 objetivo deste artigo é menos dedicarse ao enfrentamento teórico dessas diferentes posições e mais, a partir de um objeto de estudo particular, contribuir para se refletir como se organizam as diferenças no mundo social hoje, em particular nos espaços dominantes da sociedade. Assim, a noção de experiência é evidenciada como uma forma de manter a noção da diferenciação ativa - de outra forma não há a noção de luxo - sem que ela seja atribuída a noções sociais mais amplas, ligadas à distinção. Em outras palavras, a noção de experiência é uma forma de o mercado denegar a diferença como distinção. Vamos explorar, no 
mercado de turismo de luxo, a efetividade dessa noção.

\section{0 turismo de luxo}

$O$ importante é ter bagagem cultural.

E, para isso, os olhos precisam viajar.

(Diana Vreeland, editora de moda norte-americana)

0 turismo de luxo se amplia a partir da década de 1980. Isso se nota pela expansão das cadeias de hotéis de luxo. 0 Ritz-Carlton tinha seis propriedades até 1940, mas fecha aquela década com apenas uma. Em 1998, a cadeia é vendida para o Marriott e, desde então, a Ritz-Carlton expandiu-se para 68 propriedades de luxo no mundo. A rede Four Seasons não se dedicava a hotéis de luxo, mas desde 1980 se expande nesse mercado e hoje possui 65 hotéis e resorts do tipo pelo mundo. Entre 1994 e 1999, o número de hotéis classificados como cinco estrelas triplicou e aqueles classificados como luxuoso (entre os de cinco estrelas ou de classificação especial) aumentaram 31\% (SHERMAN, 2007, p. 28).

Além de sua expansão ter ocorrido justamente quando surgiu o chamado "novo luxo”, o turismo é exemplar para a questão que estamos tratando por outro motivo. Os temas da democratização e da experiência são nele centrais. 0 primeiro em decorrência da já mencionada ampliação do mercado consumidor de turismo. 0 segundo - que tem maior relevância - em razão de o turismo de luxo basear seus ganhos fundamentalmente na oferta de serviços, de modo que a experiência ganha destaque. Esses dois movimentos são promovidos pelos agentes de turismo, como se verá, e percebidos pelos pesquisadores da área, como Rachel Sherman (2007).
0 turismo de luxo é organizado por vários agentes que formam esse mercado: operadoras e agências de viagem; hotéis, empresas de transportes, empresas que oferecem os mais variados serviços; clientes; órgãos de promoção turística etc. 0 que chama atenção é que muitos desses agentes estão direta ou indiretamente organizados em uma empresa chamada rede Virtuoso. A rede Virtuoso é uma empresa criada nos anos 1950 nos EUA como uma agência de viagem. A partir dos anos 1980, sua estrutura de funcionamento se modifica, acompanhando o processo de globalização dos mercados, e passa a realizar outro tipo de operação. Seu fundador, Matthew Upchurch, se junta com investidores e passa a fornecer um serviço que o mercado do turismo não conhecia: deixa de vender pacotes turísticos, especializa-se no setor de viagens de luxo e se torna, a partir de então, uma empresa intermediária mundial, que reúne uma rede agências de turismo e mais de 1.700 fornecedores (hotéis e resorts, companhias de cruzeiros, linhas aéreas, operadoras de turismo e destinos).

Marion afirma que qualquer mercado concorrencial, como é o caso do de luxo, precisa não "apenas de uma pluralidade de fornecedores e de clientes, mas também de um acordo sobre os critérios que permitem qualificar os produtos a fim de estimar seu valor e comprá-los” (MARION, 201, p. 402). A rede Virtuoso é justamente o elemento articulador e legitimador desses critérios. Dada a singularidade de sua posição no mercado global, a Virtuoso adquire o poder de classificar o luxo no turismo.

Como vimos na lógica do mercado de luxo atual, também a Virtuoso busca expandir seus negócios ao mesmo tempo em que precisa manter a exclusividade. Sua expansão se dá de duas formas. Em pri- 
meiro lugar, pela presença global da rede. Em relação aos pontos de venda, a Virtuoso tem hoje 385 agências de viagem afiliadas e 11.429 consultores, espalhados por 37 países e 733 cidades do mundo. No Brasil, onde a rede opera desde o fim dos anos 1990, são 28 as agências de viagem afiliadas. Trata-se de agências de viagem, muitas delas tradicionais, que possuem acesso exclusivo à rede de fornecedores da Virtuoso, além de uma série de outros benefícios que serão tratados a seguir. A globalização se dá ainda pelos lugares oferecidos pelos membros da rede como destinos turísticos: o mundo todo está no catálogo de operação da Virtuoso.

Ainda, a expansão da rede se dá por aquilo que o setor chama de "democratização" do luxo. Assim, a Virtuoso não atua apenas visando às frações altas da classe dominante, mas também as frações médias. É claro que as viagens de luxo são extremamente caras. Em entrevistas realizadas no evento Virtuoso Networking Cocktail, alguns representantes de hotéis informaram que uma diária pode custar até US\$10 mil (informação verbal) $^{24}$. Mas não precisa ser assim; um quarto de hotel de luxo pode custar a partir de US\$ 500,00 a diária. Segundo Pamela Danziger (2005, p. 73), aqueles que ela chama de muito afluentes gastam em média US\$ 13,7 mil em uma viagem de luxo, mas aqueles que ela chama de afluentes gastam em média US\$ 5,5mil . Dessa forma, a Virtuoso pode atender um público relativamente ampliado. Em suas pesquisas de mercado $^{25}$ - nas quais são elencadas as tendências de destino para o próximo semestre ou ano e os principais "tipos de viagem ou formas de viajar do cliente da Virtuoso" - se aponta que, em 2015, os pacotes turísticos mais vendidos foram, em ordem de volume, viagens de lua de mel, "barganha de luxo", viagens multigeracionais/em família e viagens de aventura.

Nota-se que o tipo de viagem que representa o maior número de vendas na rede não é praticado regularmente pelo cliente: a viagem de lua de mel. Ao contrário dos outros tipos de viagem, a lua de mel é viagem rara, praticada poucas vezes na vida das pessoas. Isso significa que quem a pratica não precisa ser uma pessoa que costuma praticar o turismo de luxo. Da mesma forma que em relação à frequência aos museus estudados por Bourdieu e outros (2007; 1979), é justamente a regularidade da prática que a torna distintiva. Dessa forma, adiantamos um argumento a ser explorado abaixo: enquanto os consumidores das frações médias não estabelecem com a viagem de luxo uma relação de assiduidade e muitas vezes gastam um recurso economizado por um longo período em uma viagem, impossibilitando que voltem a viajar por um longo tempo, aqueles das frações altas, que também estão representadas nas viagens de lua de mel, têm nessas viagens um momento de sua frequente prática de viagem.

0 gerente da rede Virtuoso nos informou que um turista de luxo viaja em média quatro vezes por ano, usando os serviços da

24. A edição que visitamos ocorreu no Hotel Intercontinental, em São Paulo, no dia 02 de maio de 2016. 0 evento é exclusivo para agências e fornecedores da rede Virtuoso e nossa entrada só foi possível por convite feito pelo representante da rede no Brasil. A esse representante agradecemos não apenas pela visita, mas também por muitos materiais a que tivemos acesso e pela entrevista que nos concedeu.

25. Esses dados se baseiam em documentos internos da rede Virtuoso que nos foram cedidos pelo representante da rede que entrevistamos em oito de abril de 2016. 
rede (informação verbal). É evidente que ele tem em mente um turista de luxo ideal, ou seja, aquele que, embora não seja a maioria de seu público, dita os padrões de seu negócio. Isso significa que, muito embora as frações médias sejam responsáveis pela ampliação e por boa parte do faturamento do setor de viagens de luxo, a prática desse tipo de viagem só se constitui como habitus nas frações altas da classe dominante. Isso significa dizer que o gosto de luxo é produzido visando aos padrões das frações altas e a partir delas, que têm esse tipo de viagem em seu cotidiano. Contudo, esse gosto não se resume a elas e as frações médias buscam - muitas vezes com todos seus recursos - dele compartilhar. Unindo, portanto, uma rede global que se expande não apenas pelas frações altas, mas também pelas frações médias das classes dominantes da população mundial, a rede Virtuoso informa que suas agências afiliadas geram mais de US\$ 15 bilhões anuais em vendas.

Se o negócio do luxo se baseia na exclusividade, a rede também precisa produzi -la. Em sua própria formação isso já transparece. Suas agências afiliadas pagam uma anuidade para a Virtuoso, mas isso não basta. Para fazer parte da rede elas precisam ser convidadas por outras agências ou por fornecedores, levando em consideração, dentre outras coisas, a qualidade da agência, o tipo de público que ela atende e o lugar geográfico que ela ocupa ${ }^{26}$. Fazer parte da rede, então, estabelece uma série de vantagens. As agências afiliadas têm acesso ao catálogo de fornecedores mundiais da Virtuoso, com a garantia de serviços de "alto padrão”. Além disso, essas agências são divulgadas internacionalmente pelos meios publicitários da Virtuoso, que vão desde o site oficial da rede até revistas próprias e especializadas, como a Virtuoso Life, a Virtuoso Traveler e a Best of the Best. Por fim, elas são "treinadas no luxo" pela Virtuoso, tema que será retomado no último item.

A noção de exclusividade perpassa todo esse mercado e por uma operação de alquimia simbólica é transferida das agências (em relação à rede Virtuoso) aos clientes (em relação aos serviços ofertados). Uma das formas de transferir a exclusividade das agências - no sentido de fazer parte de uma rede exclusiva, embora ampla - para os clientes é a oferta de serviços. Se, mais uma vez, há uma rede ampla, globalizada, de pessoas que fazem parte do mercado de luxo, por meio da intensa diferenciação dos serviços essas pessoas são hierarquizadas ${ }^{27}$.

Crispin Thurlow e Adam Jaworski descrevem assim seus dias, como pesquisadores, no hotel Burj Al Arab, em Dubai:

26. A questão do lugar parece ser de extrema importância, pois é uma forma de a empresa evitar a concentração de muitas agências de viagem numa mesma cidade ou num país que vendam os pacotes da Virtuoso e assegurar a pouca competição entre elas. É o caso de uma agência filiada à Virtuoso na Colômbia (um dos principais destinos da América Latina para o ano de 2016 segundo as informações fornecidas pela Virtuoso) que tem também uma sede no Peru. Seu representante nos informou que, como o Peru é um destino antigo e, por isso, já possui representantes da Virtuoso, sua agência apenas vende os pacotes da Virtuoso na Colômbia.

27. Ver Rachel Sherman (2007), sobre a importância do serviço para o mercado de luxo e sua relação com o trabalho). 
Em dois dias de idas e vindas nós não abrimos a porta nem uma vez. Nosso mordomo indicado, Peter (não é seu nome real), estava sempre lá nos esperando. Ele esperava, nós éramos esperados. Constantemente. Trabalhando duro para sustentar nosso sentido de merecimento. Quando ele levantava rapidamente para nos cumprimentar, Peter sentava atrás do computador em sua mesa. De seu computador, Peter podia ver as nossas fotos escaneadas dos passaportes; aqui também eram registradas todas as preferências (discerniveis ou expressas) dos hóspedes: nossas demandas dietéticas, nossos horários de levantar, a fruta que nós comíamos de uma tigela no nosso quarto, o travesseiro que nós tínhamos escolhido do cardápio de 12. Por todo o hotel nós éramos reconhecidos, cumprimentados e cuidados de acordo com nossas "necessidades". Entre serviço e vigilância está desenhada uma fina linha desconcertante (THURLOW; JAWORSKI, 2012, p. 503).

Durante a pesquisa, os entrevistados mostraram a mais alta criatividade de serviços para diferenciar os clientes do luxo. Um destaca que, ao saber que uma família brasileira viajaria, acionou o hotel que a receberia para que no quarto houvesse uma lata de guaraná; assim se sentiriam em casa. Outro dizia que, depois de um longo dia fazendo turismo, tudo o que o cliente podia querer é chegar ao hotel e entrar em uma banheira. Então, o hotel antecipava o desejo do cliente e deixava a banheira pronta, com água quente e sais, para o momento do retorno do exausto turista. Carros que não poderiam ser encontrados, intérpretes, guias das mais variadas especialidades, safáris que permitem que se veja a onça que ninguém vê etc. são serviços oferecidos para alguns, nunca para todos. E, para cada serviço, um preço.

Voltamos à pergunta: como tanta diferença pode haver sem que se configurem, para os praticantes desse mercado, privilégios, diferenças sociais etc.? Mais uma vez, a noção de experiência é central. Em um folheto explicativo de duas páginas sobre "0 que é Virtuoso?", a palavra "experiência” aparece oito vezes e sempre a fim de qualificar e valorizar o serviço oferecido pela empresa. Na pesquisa de campo realizada em evento da Virtuoso, dos oito fornecedores de turismo de luxo entrevistados formalmente seis definiram luxo como experiência (informações verbais) ${ }^{28}$.

É, justamente, a reorganização simbólica do luxo como centrado no indivíduo, nos desejos e nos gostos particulares que produz um luxo que não se crê distintivo. Diante disso, é interessante identificar essa estratégia como uma denegação do social. Isso porque ela esconde, de um lado, que o gosto do turista possui relação com a sociedade que lhe predispôs a ele. De outro, que as benesses que lhe são oferecidas em experiências, de modo correspondente, não são exclusivas, mas categorizadas de acordo com o segmento social de cada turista. A frase de Lacan representa com perfeição a produção simbólica do luxo: "je dis tou-

28. Exemplos: 1. "O luxo é conforto, experiência, serviço e não ostentação" (South Africa Tourism); 2. "0 luxo é como uma experiência”; "Os clientes buscam experiência e não um hotel 'ostentação', eles buscam algo especial, a cultura local”; "0 luxo é uma experiência que você tem, diz respeito àquilo que é especial para você no mundo" (The Peninsula New York); 3. "0 luxo é uma experiência que você tem, diz respeito àquilo que é especial para você no mundo" (Tahiti Nui Travel); 4. "São as experiências e emoções que são luxo. É a intimidade de se sentir em casa” (TourismAustrália). 
jours la vérité: pas toute, parce que toute la dire, on n'y arrive pas" (1974, p. 9).

\section{Rede Virtuoso, produção do gosto e pro- dução do destino}

Turismo é imensamente poderoso em (re)organizar desigualdades e privilégios de grande escala. Na rápida expansão do 'turismo de luxo' nós achamos um flanco dessa verdadeira indústria da cultura global comprometida com a produção simbólica do status, da distinção e do privilégio da elite.

(THURLOW; JAWORSKI, 2012, p. 487)

Chama atenção nos enunciados do mercado que, nos mais variados lugares - de Nova Iorque ao Taiti - e em serviços turísticos diversos - de um restaurante a um órgão de turismo do governo -, os agenciadores do luxo produzam um discurso homólogo. Em verdade, os serviços oferecidos pelos fornecedores de luxo podem variar, mas dentro de uma mesma lógica. Partindo dos elementos que Thurlow e Jaworski (2012) notam como constantes no turismo de luxo, temos sempre: 1) oferta ilimitada de trabalho humano; 2) oferta ilimitada de tempo e espaço; 3) prazeres ligados ao corpo e ao espírito; 4) reconhecimento, familiaridade e atenção. Não é a intenção descrever o que é o turismo de luxo - os autores citados fazem isso, de diferentes modos -, mas perguntar o que torna esse padrão possível.

É evidente que uma resposta adequada para isso, ao menos na perspectiva deste artigo, passaria pela investigação do habitus de classe desses viajantes. Alguns au- tores seguiram, com êxito, por essa linha (AHMAD, 2014). A intenção que move este artigo, contudo, é focar nos agentes que reproduzem esse gosto, aqueles que Bourdieu chamaria de especialistas. Trata-se aqui da produção de um gosto globalizado ${ }^{29}$. As pessoas que participam desse mercado são de diferentes nacionalidades e vão para diferentes lugares. Para a produção do gosto, são necessários agentes que inculquem nos praticantes as formas do luxo. Isso vale tanto para aqueles que estão vendendo o luxo quanto para aqueles que o estão comprando.

Dentre os que estão vendendo, a Virtuoso desempenha papel fundamental na produção desse gosto global. Mais do que colocar agentes do mercado em contato, a principal função da Virtuoso é garantir que seus praticantes, uma vez na rede, legitimem-se como praticantes do luxo. Tudo na Virtuoso é pensado nesse sentido, do mais simples gesto até seu material impresso, suas revistas, seu site e, evidentemente, a escolha de seus colaboradores. Um desses simples gestos nos chamou atenção no trabalho de campo. Enviamos um e-mail para uma entrevista com o representante da rede no Brasil e ele, no mesmo dia, respondeu se dizendo totalmente disposto a ajudar. Pedimos, então, que ele marcasse um local, um dia e horário para uma entrevista. 0 local fixado foi o hotel Fasano, em São Paulo, um dos mais requintados da cidade. Imaginamos que ali seria seu escritório, algo previsivel para a rede Virtuoso. Contudo, encontramo-nos no café do hotel, onde realizamos a entrevista. Não havia escritório da rede ali e, portanto, não havia qualquer necessidade de se marcar o encontro

29. Nossa perspectiva se diferencia daquela de Bourdieu - que é também um dos grandes desafios atuais a sua teoria (SAPIR0, 2013) - ao pensar a produção do gosto dominante, do bom gosto, em escala global e não nacional. 
nesse hotel. É evidente que o hotel é parte da iconografia do luxo da Virtuoso ${ }^{30}$.

Outros dois elementos da Virtuoso interessam no que concerne à produção do gosto. Embora as agências sejam afiliadas à Virtuoso, nem todas as pessoas que trabalham na agência estão habilitadas a vender os serviços presentes na rede. Quando se entra no site da própria Rede, pode-se encontrar o que eles chamam de consultores, que serão indicados pelo sistema do site de acordo com as intenções de turismo do navegante. Esses consultores são, na verdade, trabalhadores das agências afiliadas à Virtuoso. Seria necessária uma pesquisa própria para tentar estabelecer relações entre o gosto desses trabalhadores e dos viajantes de luxo. Contudo, pudemos notar em nosso trabalho de campo quatro constâncias nesses trabalhadores: eles não provêm das frações altas da classe dominante; eles afirmam que o gosto pela viagem se deu ainda na infância, portanto antes de entrarem nesse mercado; eles viajam a trabalho para os lugares que vendem e usam os produtos ofertados; contudo, eles não viajam no setor de luxo em seus tempos de lazer, ou seja, com seus próprios recursos. Dessa forma, as pessoas que lidam diretamente com o cliente do turismo de luxo compartilham anteriormente a prática da viagem, mas não a do luxo. Elas precisam, portanto, ser treinadas, ou melhor, educadas sobre o que é e o que não é o luxo. É um trabalho de adequação do habitus às exigências do campo: quanto mais alinhado estiver e quanto mais natural for esse alinhamento, mais eficaz será o agente de viagem.
Esse é um dos benefícios da Virtuoso. A rede oferece treinamentos regulares para esses trabalhadores. Nesses momentos eles aprendem sobre o que é oferecido pelos fornecedores da Virtuoso, mas também sobre o que é o luxo. De um lado, são capazes de repetir que turismo se relaciona com experiência, prazeres pessoais e que "não se trata de ter dinheiro". De outro, revelam que se trata de diferenciação. Num raro momento de reflexão sobre o trabalho, a trabalhadora de uma agência fez a seguinte comparação para falar de seu trabalho:

Sabe o filme Titanic? Há o rapaz que fica no porão e a moça que fica na parte de cima do navio. 0 que eu faço é justamente isso: garantir que meu cliente fique na parte de cima e que os outros não possam subir. Acho que o que eu faço é segregar as pessoas. É isso mesmo? Será que isso é certo? (informação verbal) $)^{31}$

Outro trabalho que a Virtuoso faz com os agentes se refere aos encontros. A Virtuoso faz um grande encontro anual, em Las Vegas, reunindo toda sua rede de agentes e fornecedores. Ainda, a Virtuoso faz encontros locais, como aquele do qual participamos no Hotel Intercontinental. Nesses encontros, os fornecedores oferecem às agências seus serviços, em rodadas de negócios que duram, cada uma, cinco minutos. Contudo, mais importante para o que queremos notar é que, nesses encontros, regados a champanhe e fartos em canapés, as pessoas se reconhecem compartilhando o gosto pela viagem de luxo. Ao fim

30. A entrevista ocorreu em oito de abril de 2016.

31. Essa parte da entrevista se deu após encerrada a gravação. Anotamos imediatamente em nosso caderno, como narramos acima. Entrevista ocorreu em primeiro de abril de 2016, na agência de turismo, em São Paulo. 
do encontro que presenciamos houve sorteios de serviços de viagem de luxo para os trabalhadores das agências. A quantidade de sorteios fez com que poucos, se algum, não tenham sido contemplados com algum "mimo" (palavra recorrente para se referir aos serviços de luxo).

Doutrinados no luxo, ainda que não sejam eles próprios os beneficiados por ele, os trabalhadores se tornam doutrinadores. A expansão do luxo requer ensinamentos para seus praticantes. É evidente que aqueles que nascem nas frações altas da classe dominante são acostumados a isso na infância. Em verdade, é seu gosto pelo luxo que unifica o mercado. Peguemos as famílias que levam as crianças à Disney. Ali elas aprendem que em um mercado unificado elas devem procurar formas de se diferenciar. A criança percebe que um turista de luxo na Disney não fica na fila, como os outros, pois pode contratar um guia que sabe escolher os horários em que cada atração terá menos gente; ela se acostuma, em um passeio de navio em que estão 3.000 pessoas, a ficar em um andar exclusivo, a que só 100 pessoas têm acesso; ela aprende que, na piscina em que nada em seu hotel, poucas pessoas podem nadar ${ }^{32}$. Enfim, já na infância, aprende a se diferenciar em um mercado amplo. Essas pessoas, portanto, incorporam, de maneira inconsciente, o luxo na primeira infância; socializam-se nele e não precisam pensar sobre ele.

Aos clientes que farão da viagem de luxo a viagem da vida, contudo, os trabalhadores das agências transferem o conhecimento no qual eles próprios foram treinados: ensinam as "melhores" experiências. Dessa forma, enquanto os clientes das frações altas da classe dominante possuem um capital cul- tural incorporado - ou seja, reconhecem o luxo como sua segunda natureza, sem precisar pensar sobre ele - os clientes das frações médias precisam adquiri-lo com um grande investimento. Não à toa, relatam nossos informantes, são esses clientes pouco habituados às viagens de luxo os que mais gastam, absorvendo todos os serviços que lhes são ofertados, uma vez que eles não sabem diferenciar aqueles de fato legítimos. Na dúvida, compram tudo. Invariavelmente, os trabalhadores envolvidos na rede Virtuoso se referiram a eles de forma pejorativa.

Nota-se aqui o desvelar do sentido de experiência. Em verdade, ela significa uma forma de distinção que diferencia quem traz o luxo em seu corpo daquele que aprende o luxo. Isso se nota na forma como os destinos são escolhidos. Na pesquisa, os informantes dizem que todos os clientes da rede Virtuoso já foram a três destinos: Disney, Nova Iorque e Paris. Esses lugares funcionam, portanto, como forma de unificação do mercado, ou seja, tornam-se elementos de uma linguagem comum. Ocorre que uma parte desses clientes continua indo a esses lugares ou a lugares que ocupam a mesma posição no mercado de destinos: Cancun, Dubai etc. Nesses, eles se distinguem de outros turistas que não são de luxo usufruindo os serviços, como visto acima. Contudo, outra parte dos clientes busca novos destinos que, assim creem, eles mesmos estão descobrindo. A "escolha” do lugar se torna, assim, uma forma de distinção no turismo de luxo. De forma evidente, não são apenas os serviços que se consomem, mas também o destino que se escolhe que diferencia os praticantes no mercado de luxo.

A ideia de descoberta é presença constante nas promoções turísticas. 
Figura 01 - Imagem do website da agência paulista Primetour

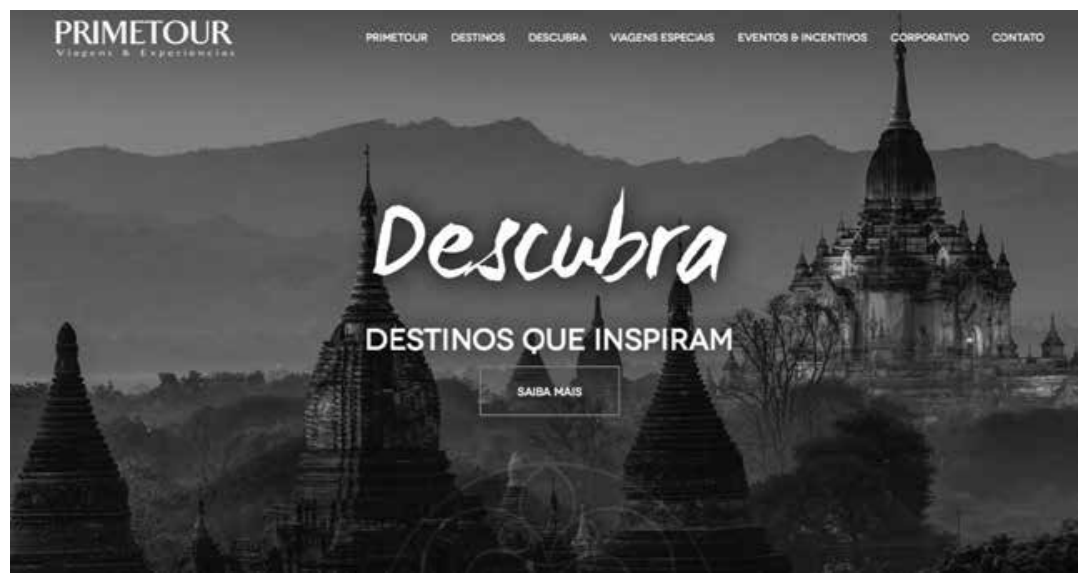

Fonte: PRIMETOUR, 2016.

Figura 02 - Imagem do website da agência paulista L'Espace

Peter Island: descubra o paraíso exclusivo no Caribe

Eus de abril de 2016 i Livasce Tours Fleave s comment

Peter island, a maior iha privativa das thas Virgens Britbnicas, o um lugar dificil de descrever em palavras. Areias brancos, tomperaturas agradáveis e praiss exuberantes sło facilmente encontradas em outros destinos do Caribe, mas poucos oferecem tudo isso com um valioso bónus: a exclusividade.

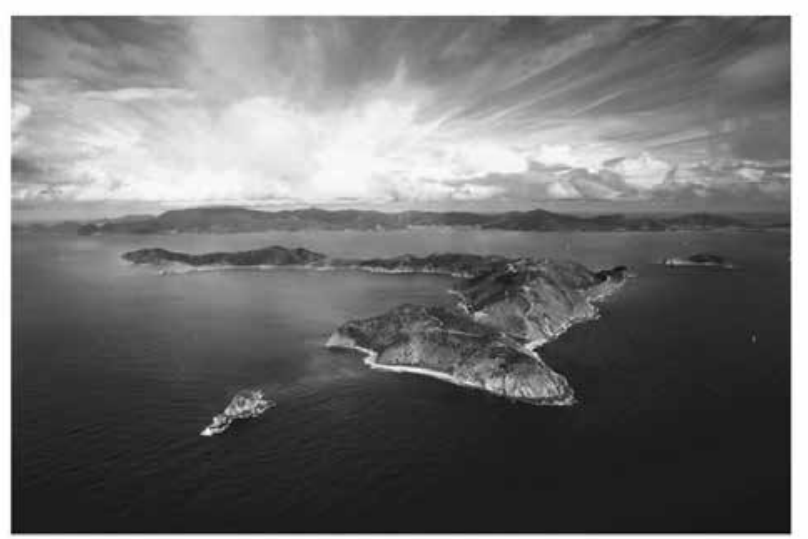

Fonte: L'ESPACE TOURS, 2016. 
De um lado, a noção de descoberta dá conta da exclusividade: refere-se à pressuposição de que todo o destino é só seu. Tanto é assim que em uma análise sobre a iconografia das promoções de viagem de luxo mostrou-se a tendência da representação do espaço vazio (THURLOW; JAWORSKI, 2012), onde se encontra um solitário turista, dono de todo o espaço. Reproduzimos imagens nesse sentido, retiradas do trabalho de campo ${ }^{33}$.

Figura 03 - Publicidade do escritório de turismo do governo do Taiti em página da revista Virtuoso Life.

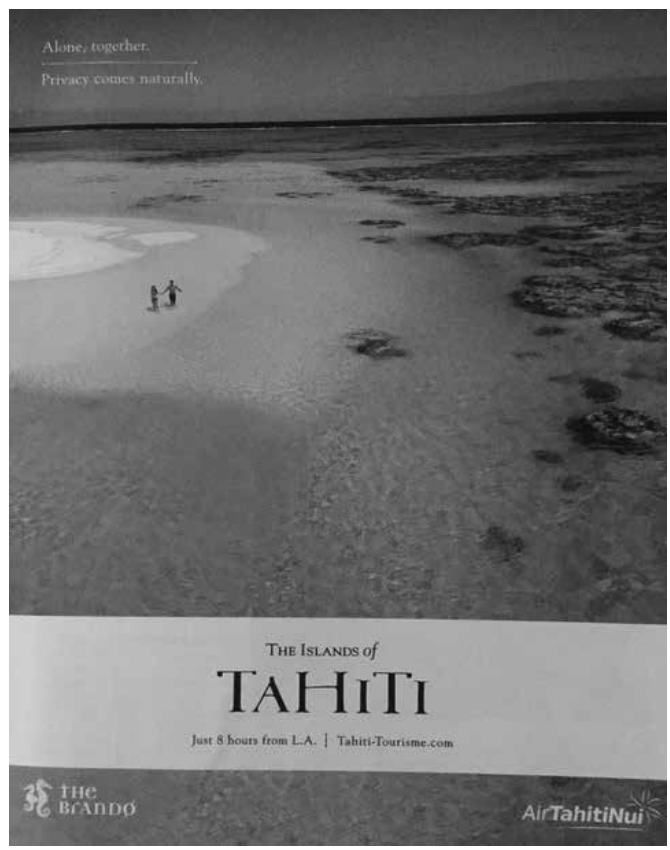

Figura 04 - Publicidade da rede Four Seasons em página da revista Virtuoso Life

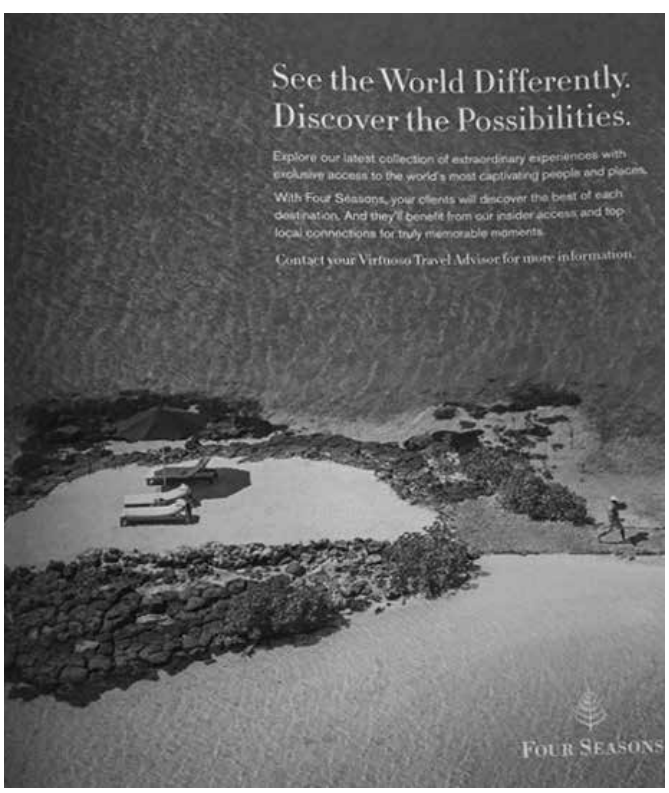

Contudo, há um elemento da noção da descoberta que interessa mais. Se o destino foi descoberto pelo sujeito que para ele viaja, o luxo também integra sua descoberta, pois não lhe teria sido dado de antemão. Desse modo, a noção da descoberta encobre que o destino foi produzido como luxo e supõe que tal produção se deu pelo próprio turista. Encobre-se, assim, que há toda uma produção para que a descoberta fosse possível.

33. As revistas que tivemos acesso são distribuídas às agências afiliadas. Nós tivemos acesso a elas em razão da gentileza de um de nossos entrevistados, que nos cedeu o material. São as seguintes referências: Figura 3: Revista Virtuoso Life, Setembro/outubro, 2015, vol. 89, p. 34; Figura 4: Revista Virtuoso Life, Setembro/outubro, 2015, vol. 89, p. 157. Em relação à figura 6, a foto foi tirada pelos autores de uma página da revista Virtuoso durante uma entrevista e, por isso, não foi anotada a referência. De toda forma, imagem igual pode ser encontrada no website da empresa. Disponivel em: <https://www.swaindestinations.com>. Acesso em 16/06/2017. A figura 5 se refere ao folder de promoção turística do governo da Suiça. Foi recolhido no evento da rede Virtuoso no Hotel Intercontinental, já mencionado. 
Para o destino ser de luxo, é necessário que haja o interesse do mercado de turismo em vendê-lo assim. No relatório da rede Virtuoso somos informados que um elemento central do turismo de luxo é a busca por lugares que estão fora do circuito mais amplo do turismo. Dessa forma, afirma-se no relatório que "os destinos que despontam como tendência para os próximos seis meses" são o continente africano, a Tailândia e o Peru. E, ainda, que os destinos preferidos do "viajante que já viu de tudo" são Japão, países da África, Maldivas e Islândia ${ }^{34}$.

Notemos que alguns desses destinos citados são, de fato, aqueles que tiveram um crescimento acentuado de recepção de turistas nos últimos tempos. A tabela abaixo mostra que Peru, Islândia, Maldivas e Tailândia possuem um crescimento no número de turistas acima da média mundial e bastante acima do país que mais recebe turistas no mundo, a França $\mathrm{a}^{35}$.

Tabela 01 - Crescimento do número de turistas recebidos por país, por ano

\begin{tabular}{|l|c|c|c|}
\hline País & 2001 & 2014 & Crescimento em \% \\
\hline Peru & 901.000 & 3.215 .000 & 3,57 \\
\hline Islândia & 301.000 & 998.000 & 3,32 \\
\hline Maldivas & 461.000 & 1.205 .000 & 2,61 \\
\hline Tailândia & 10.133 .000 & 24.810 .000 & 2,45 \\
\hline Mundo & 693.772 .530 & 1.161 .000 .000 & 1,67 \\
\hline Brasil & 4.773 .000 & 6.430 .000 & 1,35 \\
\hline França & 75.000 .000 & 83.767 .000 & 1,12 \\
\hline
\end{tabular}

Fonte: Adaptado de THE WORLD BANK, 2016.

Isso não se dá porque os aventureiros turistas de luxo os descobriram. Esses turistas apenas chegam até eles porque há um processo que envolve: 1.0 interesse do governo em produzir um plano de turismo; 2. 0 interesse de empresas de transporte, hospedagem e serviços em investir no turismo desses lugares; 3 . 0 convencimento de operadores de turismo de criar pacotes turísticos que envolvam esses lugares; 4. 0 engajamento de agências de turismo em vender esses lugares.
Todos esses destinos possuem um projeto, patrocinado pelo Estado e que envolve os investidores privados, para a promoção internacional do turismo. Esses projetos possuem representantes que viajam às feiras de turismo para incluir seus destinos nos catálogos de venda das operadoras de turismo. Embora não seja uma típica operadora, a Virtuoso faz as vezes de uma. No evento da Virtuoso em que estivemos, tal qual qualquer outro fornecedor os representantes dos projetos de turismo da Austrália, da

34. Relatório foi publicado em 2016, em referência à análise do ano de 2015. Esse é um dos documentos que nos foram cedidos pelo representante da rede no Brasil (ver nota 25).

35. Os dados ofıciais contabilizam o turismo chinês separado de Macau e Hong Kong. É dessa forma que a França se torna o primeiro destino do mundo. Somados Macau e Hong Kong, a China assume a primeira colocação, como acima foi informado. 
África do Sul e da Suiça buscavam convencer as agências de viagem presentes de que seus destinos servem ao mercado de luxo e devem ser vendidos aos clientes finais.

É evidente que a noção de descoberta é mais difícil, embora presente, em lugares com muitos turistas, como foi dito acima. No entanto, interessa notar que os lugares com menor contingente de turistas podem se posicionar como destinos de luxo. Eles são produzidos simbolicamente como tal. É o caso das Maldivas, hoje repetidamente presentes nos catálogos das agências de luxo. Isso não é aleatório. Nas feiras de turismo, nos catálogos que distribuem para as agências de viagem, os representantes do setor do país buscam posicioná-lo dessa maneira.

Assim, o destino é produzido para ser "descoberto", sendo a descoberta uma forma de individualização do luxo e, como tal, uma forma de denegação dos condicionantes sociais. Mais ainda, a descoberta, junto à experiência, encobre as bases da relação entre turistas e destinos, uma relação na qual os destinos são classificados na estrutura do turismo de luxo na mesma medida em que classificam seus praticantes. Kirshenblatt-Gimblett (1998, p. 152) afirma que, "para competir por turistas, um lugar precisa se tornar um destino. Para competir entre si, os destinos devem ser distinguíveis, o que explica a razão da indústria do turismo requerer a produção da diferença". 0 que pudemos observar é que essa diferença é produzida como distinção. Os destinos se esforçam para se tornar, em si, produtos de luxo, e a relação deles com práticas de luxo, presentes em suas promoções, deixa isso evidente.
Figura 05 - Folder Suiça Naturalmente.

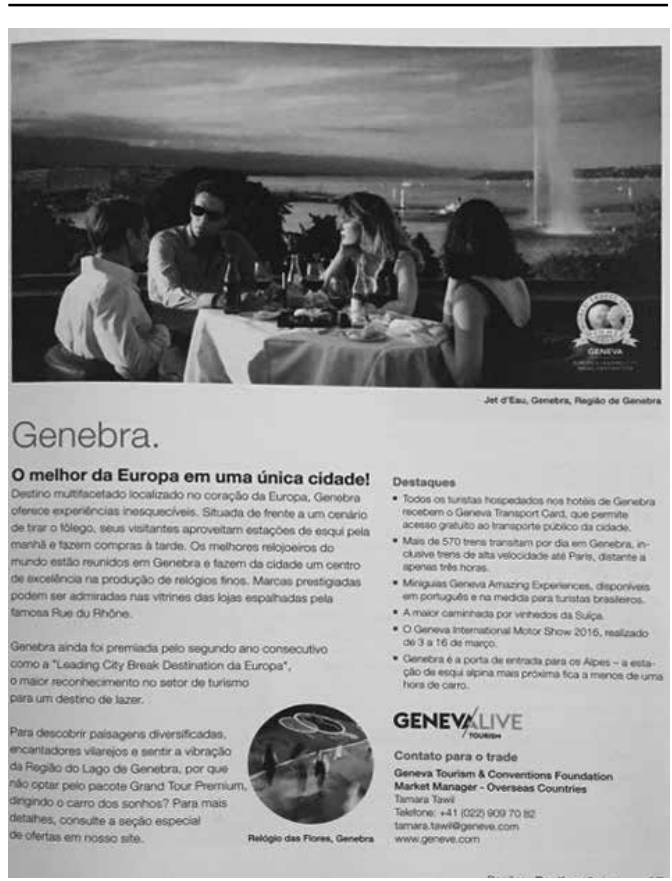

Figura 06 - Publicidade da agência Swain, sobre a Tasmânia, em revista Virtuoso.

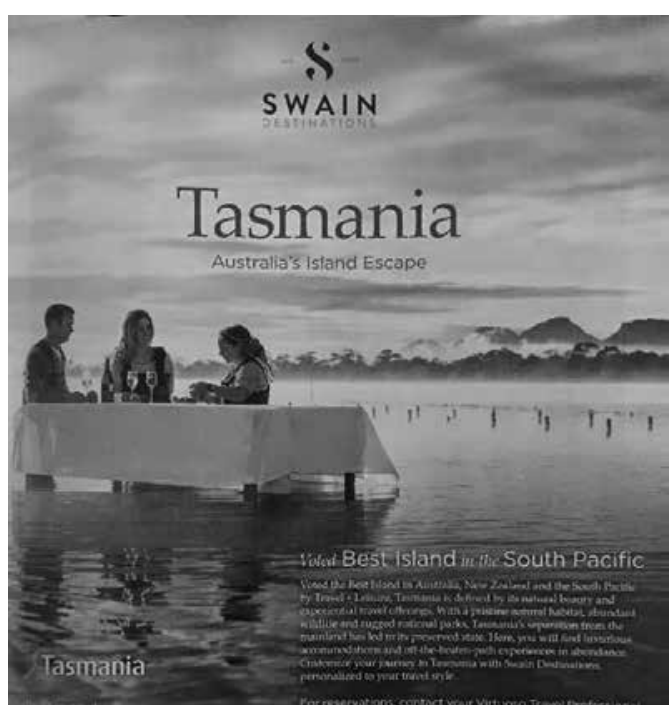




\section{Em conclusão}

A globalização significou uma nova forma de gerenciamento do luxo por empresas transnacionais. Ao contrário de algo que tinha seu valor ao ser expressamente ligado ao consumo de uma classe social, o luxo agora precisa se desvincular, discursivamente, dessa classe para expandir seu mercado consumidor. As empresas que operam o luxo buscam dar conta desse processo ao negar qualquer condicionante social do luxo, enquanto o afirmam como processo ligado ao indivíduo. Noções como experiência e democratização se tornam ubíquas nos discursos desses agentes. No mercado de turismo de luxo, notamos que os destinos se tornam produtos - como tantos outros - e, da mesma forma, seu consumo não deve ser visto como uma decisão baseada em classe, mas no ímpeto individual. Dessa forma, mobiliza-se a noção de descoberta. A pesquisa aqui mobilizada revela, contudo, que justamente pelas noções de experiência e descoberta se produz a distinção (velada pelo mercado). Os destinos podem ser apreendidos, portanto, como classificados em um mercado de turismo e em um mercado de luxo. Ao mesmo tempo, eles classificam os turistas, diferenciando os que possuem o luxo incorporado daqueles que o aprendem. A experiência e a descoberta são determinantes: velam o social que, em verdade, se afırma nelas.

\section{Referências}

AHMAD, R. Habitus, capital and patterns of taste in tourism consumption: a study of Western tourism consumers in India. Journal of Hospitality $\mathbb{E t}$ Tourism, v. 38, n. 4, 2014, p. 487-505.

ARON, C. S. Working at Play: A History of Vacations in the United States. New York Oxford: Oxford University Press, 1999.
BARANOWSHI, S. An Alternative to Everyday Life? The Politics of Leisure and Tourism. Contemporary European History, v. 12, n. 4, Nov. 2003, p. 561-572.

BOURDIEU, P. Raisons Pratiques: sur la théorie de l'action. Paris: Seuil, 1994.

Distinction: a social critique of the judgement of taste. Cambridge: Harvard University Press, 2002.

BOURDIEU, P. et al. 0 amor pela arte: os museus de arte na Europa e seu público. São Paulo: EDUSP/Porto Alegre: Zouk, 2007.

BRADY, F. Introduction. In: BOSWELL, J. Boswell on the Grand Tour: Italy, Corsica, and France, 1765-1766. New York: Mcgraw Hill Book Company, 1955, pp. ix - xxv.

BRASIL. Turismo no Brasil 2011-2014. Brasília: Ministério do Turismo/FGV, 2010.

BURNS, P. An Introduction to Tourism and Anthropology. London; New York: Routledge, 1999.

CREATIVE TOURISM. A propósito del Turismo Creativo. 2014. Disponivel em: <http://www.creativetourismnetwork.org/about/?lang=es $>$. Acesso em: 06 jun. 2017.

DANZIGER, P. N. Let them eat cake: marketing luxury to the masses - as well as the classes. USA: Dearborn Trade Publishing, 2005.

DIDEROT, D., D'ALEMBERT, R. Encyclopedie ou Dictionnaire raisonne des sciences, des arts et des metiers. Stuttgart-Bad Cannstatt: Frommann, 1988.

DUBOIS, B.; PATERMAULT, C Does Luxury Have a Home Country? An investigation of Country Images in Europe. Marketing and Research Today, May 1997, p. 79-85.

FAINSTEIN, S.; JUDD, D. R. Global Forces, Local Strategies, and Urban Tourism. In: The tourist city. New Haven; London: Yale University Press, 1999. FREITAS JÚNIOR, A. L. O Mercado de luxo e um panorama sobre o consumo de luxo no Brasil. Trabalho de Conclusão de Curso. Instituto de Economia da Universidade Estadual de Campinas. 
HIERNAUX-NICOLAS, D. Cancún Bliss. In: JUDD, D. R.; FAINSTEIN, S. The tourist city. New Haven; London: Yale University Press, 1999, pp. 124 -142 .

HOLBROOK, M.; HIRSCHMAN, E. The experiential aspects of consumption: consumer fantasies, feelings, and fun. Journal of consumer research, v. 9, 1982.

HUME, D. Of Refinement in the art. In: Philosophical works, v. 3. Aalen: Scientia Verlag, 1992.

HUNT, A. Governance of the Consuming Passions: A History of Sumptuary Law. New York: St. Martin's Press, 1996.

JUDD, D. R. Constructing the tourist bubble. In: JUDD, D.; FAINSTEIN, S. The tourist city. New Haven; London: Yale University Press, 1999, pp. $35-53$.

KIRSHENBLATT-GIMBLETT, B. Destination Culture: Tourism, Museums, and Heritage. Los Angeles, London: University of California Press, 1998.

KRAEMER-RAINE, P. Le luxe et les lois somptuaires au moyen âge. Paris: Ernest Sagot, 1920.

LACAN, J. Télévision. Paris: Le Seuil, 1974.

L'ESPACE TOURS. Peter Island: descubra o paraíso exclusivo no Caribe. Blog L'Espace Tours. 13 abr. 2016. Disponivel em: <http://www.blog.lespacetours.com/peter-island-descubra-o-paraiso-exclusivo-do-caribe/>. Acesso em: 15 set. 2016.

LÖFGREN, 0. On Holiday: a History of Vacationing. Berkeley; Los Angeles: Regents of the University of California, 1999.

LVMH. Annual Report 2014. Disponivel em: <https://r.lvmh-static.com/uploads/2014/04/lvmh_ ra2014_gb.pdf>. Acesso em: 02 set. 2016.

MACCANNELL, D. The Tourist: a new Theory of Leisure Class. New York: Schocken Books, 1976.

The Ethics of Sight-seeing. Berkeley; Los

Angeles: University of California, 2011

MANDEVILE, B. La fable des abeilles. Paris: Vrin, 1991.
MOLINA. F. S. Megaeventos e produção do espaço urbano. São Paulo: Annablume, 2015.

ORTIZ, R. Tradição e modernidade: a linha do tempo. In: Universalismo e diversidade. São

Paulo: Boitempo, 2015, pp. 63 - 88

PINÇON, M.; PINÇON-CHARLOT, M. Sociologie de la bourgeoisie. Paris: La Découverte, 2003.

PRIMETOUR. Home page. Disponível em: <http:// primetour.com.br/>. Acesso em: 15 set. 2016.

REJOWSKI, M. Turismo no Percurso do Tempo. São Paulo: Aleph, 2002.

REJOWSKI, M.; SOLHA, K. T. Turismo em um cenário de mudanças. In: REJOWSKI, M. Turismo no Percurso do Tempo. São Paulo: Aleph, 2002.

ROUSSEAU, J-J. Julia, ou, A nova Heloisa: cartas de dois amantes habitantes de uma cidadezinha ao pé dos Alpes. São Paulo: Hucitec, 1994.

Discurso sobre a origem e os fundamentos da desigualdade entre os homens; Discurso sobre as ciências e as artes. São Paulo: Nova Cultural, 1999.

SAPIR0, G. Le champ est-il national? La théorie de la différenciation sociale au prisme de l'histoire globale. Actes de la recherche en sciences sociales, Paris, n. 200, 2013, p. 70-85.

SCHULZE, G. Die Erlebnisgesellschaft: Kultursoziologie and Gegenwart. Frankfurt: Campus Verlag, 2005.

SENECA. Os pensadores: antologia de textos de Epicuro, Cícero, Seneca, Imperador de Roma Marco Aurelio. São Paulo: Abril, 1973.

SHERMAN, R. Class acts: service and inequality in luxury hotels. Berkeley and Los Angeles: University of California Press, 2012.

SHUKLA, P. The influence of value perceptions on luxury purchase intentions in developed and emerging markets. International Marketing Review, v. 6, 2012.

SILVERSTEIN, M.; FISKE, N. Luxury for the masses. Harvard Business Review. Apr. 2003. Dispo- 
nível em: <https://hbr.org/2003/04/luxury-forthe-masses>. Acesso em: 03 set. 2016.

SIMMEL, G. Filosofia da Moda e outros escritos. Lisboa: Texto \&t Grafia, 2014.

SMITH, V. Introduction. In V. Smith, Hosts and Guests: the anthropology of tourism. Philadelphia: University of Pennsylvania Press, 1989.

SUNDB0, J. The Exposure Society: experience as a new aspect of social status. In: CULTURAL PRODUCTION AND EXPERIENCE, Roskilde, Denmark. Papers. 2008.

THE WORLD BANK. World Tourism Organization. International tourism, number of arrivals. Yearbook of Tourism Statistics. 2016. Disponivel em: <http://data.worldbank.org/indicator/ST.INT. ARVL>. Acesso em 15 set. 2016.

THURLOW, C.; JAWORSKI, A. Elite mobilities: the semiotic landscapes of luxury and privilege. Social Semiotics, v. 22, n. 4, p. 487-517, 2012.

TURRELL, C. Luxury for the masses. Forbes. 13 jul. 2004. Disponível em: <https://www.forbes. com/2004/07/13/0713findsvpluxury.html>. Acesso em: 03 set. 2016.

TWITCHELL, J. B. Living it up: our love affair with luxury. New York: Columbia University Press, 2002.

URRY, J. 0 olhar do turista: lazer e viagens nas sociedades contemporâneas. São Paulo: Studio Nobel: Sesc, 2001.

VEBLEN, T. Theory of the leisure class. Worcestershire: Read Book, 2005.

VEYNE, P. O Império Romano. In: DUBY, G.; ARIĖS, P. (Orgs.). História da vida privada: do Império Romano ao Ano Mil. São Paulo: Companhia das Letras, v. 1, 1992.

WEBER, M. A ética protestante e o "espírito" do capitalismo. São Paulo: Companhia das Letras, 2004.

WEISS, T. Tourism in America before World War II. The Journal of Economic History, v. 64, 2004, p. 289-327. 
RESUMO

Em situação de globalização, o luxo se modifica. Se anteriormente seu valor se dava pela classe que o consumia, com a transnacionalização das empresas que o operam e do público que o consome a noção de classe se apresenta muito restrita às intenções expansivas do luxo. Dessa forma, agentes de mercado e autores especializados do setor passam a produzir um novo discurso, que chamam de "novo luxo": o luxo aparece como uma decisão individual, desvinculado de qualquer condicionamento social, mais bem caracterizado por expressões como experiência e descoberta. A noção de distinção perderia, segundo se advoga, a relevância explicativa para se pensar o luxo. Neste artigo enfrentamos esse discurso com os resultados de uma pesquisa de campo baseada no mercado de turismo de luxo. Para tanto, entrevistamos agentes de turismo e representantes de uma empresa de operação mundial chamada rede Virtuoso, que busca reunir fornecedores, vendedores e compradores de luxo. Concluímos que o luxo repõe fronteiras de classe, que são denegadas, e que os próprios destinos turísticos funcionam como marcas de classificação nesse mercado.

\section{PALAVRAS-CHAVE}

Luxo. Turismo. Globalização. Mercado. Consumo.

\section{ABSTRACT}

Luxury has changed in recent times, with the process of globalization. If the consuming practice of the dominant class had previously produced its value, since the transnationalization of companies that operate it and of its consuming public, the notion of class has become too restricted to the expanding efforts of luxury. Therefore, market and luxury experts produce a new discourse, one they call the 'new luxury'. According to it, luxury should be seen as an individual decision, unrelated to any social condition, a matter of experience and democracy. The notion of distinction should lose its explaining relevance in order to think about luxury. In this article we confront this discourse with the results of a fieldwork based upon the tourism luxury market. Our investigation was focused on a central agent of this market, the Virtuoso Network, a company that brings together in network sellers, suppliers and buyers of luxury. As our findings will show, the destinations themselves are marks of distinction, as they classify the visitors as much as they are classified by them.

\section{KEYWORDS}

Luxury. Tourism. Globalization. Market. Consumption. 